\title{
Between Utility and Rights: The Expected Changes in Tom Regan's Defence of the Right of Animals
}

\author{
Dr. Omotosho I.F. \\ Lecturer, Federal Polytechnic Ede
}

\begin{abstract}
The theme of Tom Regan's writings on animal rights is to influence the attitude and change the beliefs of people that animals are resources or property. For Tom Regan, The idea that non human animals are property is the reason for the exploitation and use of animals. His theory, though well argued has been unpopular and neglected especially by scientists. This paper examines why Regan's defence of animal rights has not gained much acceptance and influence, thereby failing to change the attitudes of people especially scientists toward non human animals and the belief that they are resources. The paper, having used the method of philosophical analysis and critical argumentation reveals that Regan's deonlological absolutism and his failure to recognise some of the implications of granting rights to animals for scientists - that scientists owe society a duty while they need to respect animal rights at the same time are some of the problems among others with Regan's defence of the right of animals. All these have made the defence seems unacceptable and 'impracticable'. The paper then suggests changes that will make the defence acceptable to scientists, science and influence people's attitude positively toward nonhuman animal status and rights.
\end{abstract}

Keywords: Rights view, deontologism, defence. Property, animal rights, human animals, non-human animal.

DOI: $10.7176 / \mathrm{JPCR} / 40-02$

\section{Introduction}

Non human animals are used for food, for experiment in laboratories, for sports, for economic gains. All these involve inflicting pain and discomfort on the non human animals . Non human animals are butchered without considering whether they like it or not or conscious of it or not. In bullfighting sport, bulls suffer severe stress and a slow tortuous death. In our laboratories .unnecessary suffering and pain are inflicted on non human animals during scientific experiments and demonstrations. The cause of this treatment of non human animals like this is borne out of our belief that other animals are our resources or property according to Regan(1986; 180,181).

Thus, one of the main motives of Tom Regan's defence of the right of animals is to influence our attitude toward animals and change our belief that non human animals are our resources ( Regan 1986, 180). For him our attitudes towards animals that they are our property and so must be exploited and used need to be changed because animals are like us and so deserve moral rights.

However, this paper argues that there are some flaws in the defence which have made the defence unacceptable and impractable. To achieve the aim of the defence- to change our attitude toward non human animal, this paper proposes some changes to Regan's defence of the right of other animals.

\section{RESEARCH METHODOLOGY}

The research used both published and unpublished materials, including books, journals and the internet. The philosophical methods of analysis, rational and critical argumentation were employed.

\section{TOM REGAN'S DEFENCE OF THE RIGHT OF ANIMALS}

Tom Regan, An environmental ethicist and philosophical defender of the rights of animals argues that nonhuman animals are like us and so, are bonafide bearers of rights. He argues further that since non-human animals are subjects of a life like us by virtue of their sentience and mental capabilities such as memory, belief, desire and so on they have inherent value, which for Regan is the criterion of moral considerability and thus deserve moral rights like us. The crux of his argument is that since the moral rights of humans are based on the possession of certain cognitive abilities and since these abilities are also possessed by some non-human animals since they are like us - these non- human animals deserve the same moral rights as humans (Regan 1983, $243,244)$.

According to Regan, all subjects of a life, without regard to voluntary acts, or institutional arrangements must have their inherent value respected. He argues that the reason why we treat all human beings as if they have inherent value is because they are experiencing subjects-of-a-life that is, they are conscious, entertain beliefs, have interest in what happens to them etc. Since some non human animals are subjects- of-a-life also, he concludes that they have inherent value like us (Takaoka,2015, 61-65). Consequently, they must be treated as valuable in themselves not as mere receptacles of values - containers for happiness or preferences (Regan 1983, 236 -238). They cannot be harmed on the basis that the net benefit justifies it Non-human animals like us 
deserve rights because they are conscious like us.

Like us, non human animals consciousness is complex. We know this not only through common sense, but because of their similarity to us, behaviorally and physiologically (Regan 1983, 28-29). Thus, the welfare of non- human animals, according to Regan's argument, is no different in kind from human welfare (Takaoka, 2015, 68). This is because non-human animals are like us.

Regan employed this "like us" strategy of identification (Omotosho 2017, 121-137) to call into question. the question of human exceptionality - that we are different from non-human animals. He also used this strategy to expand our moral community. If they are like us, Subject - of - a - life - and we are entitled to moral consideration, they are also entitled. Such creatures can be harmed or benefitted like us. Creatures with such capacities are said to be subjects of a life and as such have inherent value and thus should not be treated as a means to an end (Omotosho 2017, 131-145).

\section{EXAMINATION OF REGAN'S DEFENCE OF THE RIGHT OF ANIMALS}

Contrary to Regan's view, Frey argues that since non human animals do not have language, they lack not only self-consciousness but beliefs also. Since they lack beliefs and self-consciousness, they cannot have consciously held desires. Lacking such desires, Frey concludes, non human animals have neither interests nor moral rights. Thus, for Frey, since other animals lack language, they cannot have interest. Since it is interest that entitles humans to moral consideration and since non human animals lack this quality, they have no claim to moral status or rights Frey argues further that one cannot have a desire without a corresponding belief (Frey, 1980, 39). Non human animals cannot have beliefs because they are unable to comprehend the concept of a belief, that is, they are unable to hold a second order belief - a belief about belief. For example, if a goat gets close to the doorway and turns back because the door is locked , If someone say "the goat believes the door is locked", then that person is holding, according to Frey, that the goat holds the declarative sentence, "The door is locked", to be true (Frey, 1980, 40). There is no ground whatever for crediting the goat which lacks language with entertaining declarative sentences. Thus, goats or animals in general have no interests. Since interest is what gives moral consideration to humans on the preference utilitarian theory, then non-human animals do not deserve moral consideration and so have no moral rights, according to Frey (Frey, 1980, 40).

However, DeGrazia David has argued that first order beliefs may be held in the absence of second order beliefs. A human or non-human animal can hold a belief while failing to understand the concept of belief. So, a human infant and non-human animal can hold beliefs. Thus, language is not necessary to having a belief and consequently interest. Humans could not have developed language without some preverbal beliefs, according to DeGrazia (1991, 48-70)

Regan like DeGrazia, also criticized Prey's view on language. Regan rebuts Frey's view that mentalistic terms such as belief, memory, desire etc cannot be applied to non-human animals that do not use a human style language. For Regan only animals that are subject-of-a-life are qualified for moral consideration. This is because they have inherent value and so subject of life should be treated as ends in themselves and not as a means to an end (Takaoka 2015, 66). This idea grew out of Regan's opposition to utilitarianism. According to Regan, utilitarianism moral theory can justify the harm done to one individual by the production of a greater "net benefit to other individuals (Regan 1983, 235, 236). Instead of utilitarian's (such as Singer) proposal of interests as qualification for moral consideration, Regan proposes inherent value which only subjects of a life have or possess.

Regan's position has been criticised as a strong animal rights position by Mary Anne (I987, 433-441). Mary Anne therefore argues for a weak animal rights position; that animal rights are weaker than human rights because humans are rational while non-human animals are not (1987, 433-441). It may be argued that Mary Anne's submission that animals are irrational is questionable as there are scientific proofs today that animals are rational. (Omotosho, 2017, 77-83)

Animals have been found to be rational and intelligent. A good example is Koko, the gorilla. In his interaction with Koko, Steven Wise acknowledged that Koko is said to have learned the ability to use about 500 signs and gestures in America sign language. Koko has learnt a human language which is thought to be a feat that can only be performed by man. The intelligence tests used on Koko, the gorilla put her intelligence at the intelligence level of near five year old child. Koko's case has shown that some animal species (like apes) may have many abilities beyond the scope of human intelligence measures, as demonstrated by Koko. Koko also surpasses the human yardstick evaluations(Wise, 2002, 207).

According to Natalie Evans $(2013,70)$ The study of animal cognition relies on the assumption that animals are agents, even if only minimally so. Fred Dretske (a psychologist) also argues that some animals are minimally rational, as opposed to biologically rational or fully rational (Dreske,2006, 107).So, Wise (2000, 220) employs a critical and right based strategies to argue that chimpanzees and bonobos deserve some basic package of "personhood" rights including the right to have their interest represented in court. He argues that some animals who are like us should be considered persons not property and thus be accorded rights that will protect them 
from cruelty (Wise, 2000, 362). The essence of Wise's argument like Regan's, is that individuals with similar cognitive capabilities should be treated alike regardless of their species. For Wise, like Regan, rights are not based on genes.

At this juncture, it is noteworthy that Wise's arguments which are based on similar logic, common reasoning and "capacity orientation' like Regan's failed when tested in practice (in court). In fact, according to Adrian Morrison $(2009,60)$ few philosophers besides Cohen and almost no scientists bother to dispute in detail the philosophy behind the animal rights view. Morrison is of the view that most scientists and philosophers "think the subject to be too far from reality to be worth the trouble"(2002). This may not be unconnected with the fact that Regan's defence of the right of animals (his rights view) have been difficult to practicalise or implement The reason for this may not be far from the defects in Regan's defence of the right of animals such as Regan's failure to look critically at the implications of granting rights to animals for scientists and scence in particular.

\section{THE EXPECTED CHANGES IN TOM REGAN'S DEFENCE OF THE RIGHT OF ANIMALS}

Regan's defence of the rights of animals lays so much emphasis on his deontological absolutism with total disregard all manners of utilitarian consideration(Takaoka;2015, 60,61).By deontological absolutism, it is meant strict adherence to the doctrine of deontological ethics. Deontological ethics is an ethical theory that evaluates moral actions based only on doing ones duty not on the consequences of action as utilitarians will want us to belief. The central claim of deontologists is that certain types of acts are intrinsically right or wrong. For the deontologist, it is duty for duty sake (Omotosho, 2017, 17,18). So, for Regan, since animals are like us, they have the same inherent value or moral worth like us and must be accorded 'equitable" rights. According to Regan, we are duty bound to treat non-human animals as ends just as we treat human beings as ends and not as means. Non -human animal rights must be respected. . Thus non-human animals must not be used for food, experiments in- laboratories, hunted and so on. . In short the use and exploitation of non human animals must stop according to Regan. For Regan, utilitarianism would only license the continue use and exploitation of animals because it lays emphasis on what is good and beneficial not acts that are right. For utilitarian the end justify the means and so right can be sacrificed. In fact, in Regan's critique of preference Utilitarianism of Singer, Regan seems to have argued convincingly that utilitarianism could license acts that are wrong and that rights must be postulated as a safeguard against such acts (Omotosho,2017, 235-237).

However, Regan's cogent argument against utilitarianism notwithstanding, utilitarianism is not without any advantage as Regan wants us to believe. Utilitarianism could be seen as a value system or method of respecting individuals indirectly by protecting them en masse. There are times when looking to the interest of the individual non-human animal is appropriate (or directly is at stake) and at times when the interest of the generality (all) of the non-human animals (species is at stake) that is, general welfare instead of individuals and the method of utilitarianism may be well suited,. Then the Synthesis between the rights view and utilitarian method with regard to the treatment of non-human animals may be necessary(Omotosho,2017, 8)

However, someone may demand the reason for the adoption of two ethical views. Adoption of two ethical views may be necessary because ethics remains a contentious issue, there "is no one agreed method of resolving ethical conflicts. Combining utilitarian theory and deontological theories may give us the opportunity to fulfill our responsibility to scientists, science and at the same time be sensitive to the importance of animal life (Micheal.2002, 57-61). For instance, application of this proposed synthesis of the two ethical theories might allow us to approve an experiment that causes moderate pain to an animal since this is justified by the benefits arising to humans and non-human animals.

So also, by focusing narrowly on the rights and interest of animals, there is a danger of not paying sufficient attention to questions raised by the interconnectedness and interdependence of all life. As Donelly and Nolan(1990, 2) observe "We genuinely want to learn from the various ethical arguments for and against the use of animals in science. But we are weary of 'grand simplified, and no one philosophic theory or perspective seemed fully adequate to the problem at hand". What do we do when there is a moral dilemma - when there is an epidemic and there is a proposed drug that must be tested on a life that has value? Do we allow everybody to die? If there is no alternative to using life, then what will happen to research and development? Should scientistsespecially physicians neglect their duty to save lives? Should not we consider the plight of others concerned?

If there is an epidemic claiming both human and non-human animal lives and there is the need to test a potential drug which has the highest probability of curing the disease on a life, Should it not be tested on nonhuman animals? Should everybody and .non-human animals be left to die? These and other, questions need to be answered by Regan, It might ne argued that Regan coceeds in the life boat situation that animals could be used to serve the interest of man

However, he has argued that it is consistent with his position that animals should not be used for experiment because the animals are corcievely put at risk that animals could be used to serve human purpose.but this case differs because they run the same risk human animals run. Invoking the harm principle, Regan argues that no one has a right to have his lesser harm count for more than the greater harm of another. Thus, if death would be a 
lesser harm for the dog than it would be for any of the human survivors then the dog should thrown overboard not because the dog does not have equal right like humans(Regan,1985,2)In the opinion of this paper ,this seems to be a contradiction because of Regan's deontological position.

Thus, the two options of Regan-the use of non human animals by humans or non-use of non human animals at all, seem unable to settle the matter at hand. There is the third option to use non human animals when there is no alternative with due respect to their sentience. The right of an individual should not take precedence over the safety of the whole species, it is contrary to our intuition. Nature seems to support mutual interdependence, so it would be contrary to nature if animals cannot be used in experiments that will help sustain human and nonhuman life health wise when necessary. It should be noted that rights can be negotiated. Rights Should be given only to individual non human animals and subject to negotiation during Crisis or emergency.

This position of Regan of either the use of non human animals by humans or not using non human animals at all is also unacceptable because it presumes that our relationship with non-human animals is a one sided issue, that the relationship benefits man alone. Therefore, Regan's position overlooks many beneficial relationships between human and non-human animals where by non-human animals are not treated merely as a means to fulfil the interest of humans alone. The human - non- human animal relationship is a mutual one contrary to Regan's claim that it is a relationship of exploitation and use of non-human animals by man. For instance, animal assisted therapy, finding cure for animal ailments, protecting a species from extinction are some of the benefits of non human animal and human animal relationships to non human animals.

However, there are some questions that -must be addressed if rights are to be accorded non-human animals as Regan proposed in his defence; if we grant animals right from torture for instance, if animals break the law, what happens?. Since non-human animals do not act or are expected to act based on morality, should non-human animals be arrested? Should the law be broken since they are protected from torture? Does the law not to kill or torture apply only to humans to restrict human activity so that other animals can enjoy greater freedom and rights? Regan seems to overlook the fact that the rights of non human animals are not an isolated matter. The legitimate duty of government is to protect the rights of its citizens. What should the government do if non-human animals trample on the rights of its citizens Since non-human animals have rights (not to be tortured)? Should non-human animals be treated as citizens and if so. on what grounds? Should non-human animals' offences be overlooked? Regan need to provide answers.

Regan's defence also overlooks the fact that moral thinking can work in more than one direction. Moral thinking can work both ways .You might release laboratory non human animals waiting to be experimented on because you see your actions as your duty to animal kind. However, someone might condemn releasing laboratory non human animals because he believes his first duty is upholding the law and the standard of society as he sees it. Just as we have duty towards animals, scientists have duty towards society and humanity. For instance a researcher might keep an animal in pain because he believes he has a responsibility to find a cure for a disease. However as your duty to animal kind you might devote yourself to saving wildlife from ranchers or might release laboratory non human animals used in experiments. Deontological absolutism alone may not be able to resolve these issues.

\section{CONCLUSION}

This paper has examined why Regan's defence of the right of animals have not achieved the desired objective of changing the attitudes of people especially scientists and science on exploitation and use of animals in laboratories and the status of animals as property. Among the reasons why Regan's defence of the right of animals have failed to achieve the above mentioned aims are; Regan's tendency toward deontological absolutism in total disregard to all manners of utilitarian considerations; Regan's failure to address the interrelationship of the stake holders vis a vis animal rights. Regan's failure to see that just as animals deserve rights, scientist have moral rights to perform their duty to society and humanity.

Consequently the paper observes an ethical theory is not enough to resolve these lingering issues. .Regan's thesis has been shown to be unacceptable because scientists too have a responsibility to society. It has been shown that moral thinking can also work both ways .

Since animals possess the qualities we possess minimally, animals deserve rights like us but our rights should take precedence over theirs. In cases of dilemma as raised earlier on what to do during epidemics and when there is the need to use a life to test a drug with high probability of curing an ailment such as aid, non human animals should be used. Thus, nonhuman animals deserve rights but with proviso.

However, since non human animals possess the characteristics we possess they should not be used for frivolous experiments. Alternatives to using nonhuman animals should be looked into and funded to put an end to using nonhuman animals since they are like us. They deserve the right not to be inflicted with unnecessary pain. 


\section{REFERENCES}

Adrian Morrison, (2009) An odyssey with animals: A vetenarian Reflection on the rights and Walfare Debates, Oxford University Press: New York.

DeGrazia, D. (1991):"'The Moral Status of Animals and Their Use in Research" A Philosophical Review Kennedy Institute of ethics journal vol. 1 no 1 March, 1991 48-70

Drestke, F. (2006) "minimal rationality" In Huly Susan and Nudds Matthew (eds) Philosophical: Rational Animals? Toronto: Oxford University Press.

Donnelly S and Nollak (eds.)(1990), "Animals Science and Ethics", Hastings Centre Report, Special Supplement 20(3)p.2

Frey R,G (1980) Interest and Rights: The Case Against Animals Oxford: Clarendon Press.

Mary Anne. (1979). "Difficulties with the strong Animal Right positions Retrieved fromhttp//digitalcommons.calpoly.edu/cgi/viewcontent.cgi?article=1475\&context=bts

Micheal W.(2002) "Toxicological tests on animals: Ethical Possibilities" Ausralian Journal of Ecotoxicologyvol. $8,57-61$

Natalie E.(2013) "'Agency And Antonomy:A new Direction For Animal Ethics'1, A Thesis Submitted to the University of Waterloo in fulfilment of the thesis requirement for the degree of Doctor Of Philosophy in Philosophy.

Omotosho I.F.(2017) "A philosophical Defence of Aminal Rights" A thesis submited to the Obafemi Awolowo University in partial fulfillment of the requirement for the award of the degree of Doctor of philosophy in philosophy.

Regan,T,(1983) The Case for Animal Rights Berkeley: The University of California Press.

Regan, T 1985 )' 'Tom Regan, reply by Peter Singer'" Ten Years of Animal Liberation January 17, 1985 issue

Takaoka, B., (2015). "Speciesism: What is it? What Should We Do About it?"

Honors Thesis Collection.283.https://repository.wellesley.edu/thesiscollection/283

Wise, S. (2000)., Rattling the Cage - Towards Legal Rights for Animals, London: Profile Books. 